\title{
KEBIJAKAN DAN STRATEGI MONETER : Sebuah Keterkaitan
}

\section{Overview}

\section{Difi Johansyah *)}

Membicarakan kebijakan moneter tanpa, baik itu secara eksplisit maupun implisit, menyentuh masalah manajemen maupun strategi moneter, dapat membuat kita melupakan satu aspek mendasar yaitu aspek pencapaian tujuan dari kebijakan moneter itu sendiri. Dalam tataran strategis apal agi sudah menyangkut operasional, kebijakan moneter menuntut adanya suatu sistematika ataupun proses pencarian alternatif "terbaik" bagi pencapaian tujuan kebijakan moneter, yang secara umum diartikan sebagai stabilisasi harga, khususnya inflasi.

Keasyikan kita, khususnya peneliti ekonomi/ moneter, dalam substansi yang bersifat keilmuan dari moneter dapat membuat kita kurang memperhatikan aspek efektifitas/ pencapaian dari kebijakan moneter itu sendiri, khususnya dalam suatu langkah yang terukur dan sistematis. Disatu sisi pengkajian mengenai moneter memang disibukkan dengan kompleksitas dari permasalahan moneter yang ada, yang membuat pencarian solusi/ strategi moneter menjadi sangat sulit.

Namun di sisi lain kompleksitas masalah moneter ini justru membuka peluang adanya suatu urut-urutan penyelesaian masalah yang juga bersifat dinamis. Kendala yang banyak dijumpai dalam pelaksanaan kebijakan moneter harus disadari tidak mungkin diselesaikan sekaligus dan hanya dengan melihat prioritas kepentingan yang ada kita mampu membangun kerangka kerja yang optimal menurut kondisi yang ada. Terlebih lagi dalam situasi ekonomi makroyang juga sangatsulit seperti sekarang ini. A papun kebijakan moneter yang dipilih, adanya manajemen moneter yang efektif tetaplah diperlukan.

Sebagai catatan, saya merasa ada dua hal penting yang membuat kita lebih banyak membicarakan dan menyebut istilah kebijakan moneter dibanding dengan manajemen moneter. Yang pertama adalah kita seringkali memformulasikan suatu kebijakan moneter yang boleh dibilang samauntuk perkembangan apapun di perekonomian. Contohnya adalah

*) Difi A. Djohansyah : Peneliti Ekonomi di Bagian Analisis Perencanaan Kebijakan, DKM. 
statement "kebijakan moneter yang berhati-hati", yang sangat sering kali kita formulasikan dalam berbagai kondisi ekonomi seperti booming, overheating, maupun jugasemasa krisis. Sebagai akibatnya formulasi strategi yang adapun dapat bersifat umum untuk setiap kondisi dan membuat kita "overlook" terhadap pentingnyalangkah-langkah pelaksanaan kebijakan moneter atau strategi yang jelas, terarah dan terukur.

Dalam hal ini saya melihat makna "kebijakan moneter yang berhati-hati" merupakan makna yang dapat dipahami namun tidak demikan halnya dengan "strategi moneter yang berhati-hati". Dalam hal yang terakhir ini mungkin lebih cocok digunakan istilah, kalaupun mau dibilang umum, "strategi moneter yang efektif". Dari perbedaan dua istilah ini sajakita paling tidak dapat menangkap dua hal yang berbeda antara kebijakan dan strategi moneter.

Kebijakan moneter secara sendirian tidak akan mampu menjawab tantangan tersebut tanpa didukung oleh beberapa hal yakni :

Pertama, adanya sasaran yang jelas, terfokus, dan realistis serta tidak menimbulkan arti ganda.

Kedua, adanya instrumen untuk melaksanakan kebijakan moneter itu sendiri yang efektif

Ketiga, kerangka kerja dan infrastruktur yang mendukung pelaksanaan operasional dari instrumen moneter tersebut

Keempat, kepercayaan pasar dan pelaku ekonomi akan kredibi litas dari Otoritas Moneter.

Keempat faktor di atas haruslah dirumuskan oleh strategi dan manajemen moneter yang baik. Bagi Bank Indonesia, hal ini sangat penting mengingat tugas Bank Indonesia saat ini telah lebih fokus sebagai otoritas moneter namun disisi lain juga dituntut profesional ismedalam menjalankan tugas yang telah terfokusini.

Buletin ini mencoba mengetengahkan beberapa pemikiran ataupun obyek pengkajian di Bank Indonesia dalam rangka mencari strategi moneter yang sesuai. Mungkin daftar pengkajian yang ada ini tidaklah terlalu komprehensif namun dapat dipahami mengingat kompleksitas permasalahan moneter yang ada di Indonesia. Disamping itu, tulisan yang ada ini secara mendasar telah mewakili beberapa elemen yang disebutkan di atas.

Tulisan pertama mengenai pengukuran inflasi ini mencoba membedah permasalahan di seputar inflasi. Inflasi secara umum menunjukkan kecenderungan perubahan hargayang disebabkan oleh perubahan sisi penawaran dan permintaan barang dan jasa. Dalam konteks perekonomian Indonesia, masih banyak aspek diluar kendali moneter yang dapat mempengaruhi kecenderungan harga tersebut. Disamping itu, beberapa komoditas harga pokok diatur oleh Pemerintah melalui berbagai mekanisme yang ada dan inipun diluar jangkauan Bank Indonesia untuk mengendalikannya. Tulisan ini menjadi penting untuk menunjukkan bagian dari inflasi yang dapat dikatakan merupakan tanggung jawab Bank 
Indonesia sebagai otoritas moneter. Dalam hal ini dicoba dipisahkan antara inflasi inti (core inflation) yang dipengaruhi moneter dan inflasi sesaat (noise) yang tidak dipengaruhi kebijakan moneter.

Mengiringi tulisan pertama ini, makalah kedua mengetengahkan mengenai upaya pengukuran target inflasi dalam kaitannya dengan implementasi kebijakan moneter secara forward looking. Mengingat adanya time lag antara kebijakan moneter dengan sasaran akhir yaitu inflasi, maka penetapan sasaran inflasi haruslah dilakukan secara realistis dengan diiringi oleh strategi moneter yang memiliki waktu yang cukup untuk mencapainya secara bertahap. Suatu makna yang penting dari makalah ini adalah bahwa efektifitas pencapaian inflasi oleh suatu strategi moneter bersifat relatif, tergantung dari jangka waktunya karena adanya time lag seperti yang saya singgung. Bagi Bank Indonesia ini sangat penting agar antara inflasi dan kebijakan/ strategi moneter dapat didudukkan dalam proporsi yang realistis.

Upaya strategi pencapaian inflasi dibahas dalam tiga makalah yang lain. Sebuah makalah mengenai "Mekanisme Pengendalian Moneter Dengan Inflasi Sebagai Sasaran Tunggal" mencobamenyarankan perumusan strategi moneter melalui transmisi suku bunga. Suku bunga jangka pendek dapat berfungsi sebagai target operasional kebijakan moneter untuk mempengaruhi agregat demand dan selanjutnya pencapaian sasaran inflasi. Dalam hal ini , sebagai acuan bagi strategi moneter, disarankan adanya monetary policy rules yang dikembangkan dari Taylor ruleguna mengendalikan suku bungajangka pendek ini dalam mencapai sasaran inflasi. Walaupun demikian, rule tersebut tidak dimaksudkan untuk digunakan secara kaku (strict). Dalam hal ini, masih tersedia ruang bagi kebijakan yang bersifat discretionary, yaitu dengan melakukan assesment atas informasi yang diperoleh dari berbagai information variables.

Mirip dengan topik yang disinggung sebelumnya, makalah mengenai "Suku Bunga Sebagai Salah Satu Indikator Ekspektasi Inflasi" membahas penggunaan suku bunga dari sudut pandang lain. Dalam hal ini transmisi yang diteliti adalah reaksi masyarakat dalam bentuk memegang aset finansial terhadap ekspektasi inflasi kedepan. Perubahan dari ekspektasi inflasi ini akan berpengaruh kepada perilaku keuangan masyarakat. Oleh karena itu ekspektasi inflasi kedepan ini dapat juga dicerminkan dari perkembangan suku bunga nominal perbankan yang mencerminkan suku bunga riil dan ekspektasi inflasi masyarakat.

Pendekatan lain dalam strategi moneter selain melalui jal ur suku bungaadalah melalui jalur nilai tukar. Dalam kenyataannya apabila kita melihat perkembangan historis kebijakan moneter di Indonesia, jalur nilai tukar ini telah banyak berperan penting. Perkembangan nilai tukar walaupun dalamjangka pendek sangat dipengaruhi oleh sistem nilai tukar yang ada, namun dalam jangka panjang cenderung menuju kearah keseimbangan internal dan 
eksternal dari struktur perekonomian yang ada. Dalam hal ini, struktur perekonomian memiliki karakteristiknya sendiri-sendiri yang dipengaruhi oleh interaksi dinamis berbagai variabel yang ada. Untuk menelaahnya terdapat pendekatan melalui sumber gejolak dan pendekatan kredibilitas yang terkait dengan penjangkaran nilai tukar. Dalam makalah ini mengingat kompleksitas yang ada dal am pendekatan kredi bilitas maka pembahasan empiris hanya dibatasi pada sudut pandang karakteristik struktur perekonomian dan sudut pandang sumber gejolak (source of shock). 